\title{
Micronucleus Assay and Heavy Metals Characterization of E-waste Dumpsites in Lagos and Osun States, Southwest Nigeria
}

\author{
${ }^{1}$ *IGBO, JK; ${ }^{2} \mathrm{CHUKWU,} \mathrm{LO} ;{ }^{1,3}$ OYEWO, EO; ${ }^{3} \mathrm{ZELIKOFF,} \mathrm{JT;}{ }^{4} \mathrm{JASON}, \mathrm{BL}$ \\ ${ }^{1 *}$ Department of Biological Oceanography, Nigeria Institute for Oceanography and Marine Research, Lagos, \\ Nigeria.Email: igbojulie@yahoo.com \\ ${ }^{2}$ Department of Marine Sciences, University of Lagos, Nigeria \\ ${ }^{3}$ Department of Environmental Medicine, New York University School of Medicine, 57 Old Forge Road, Tuxedo, NY, United States
}

\begin{abstract}
The contamination of the aquatic ecosystem with heavy metals arising from the discharge of electronic waste (e-waste) or seepage of leachate from open waste dumpsites is on the increase. The impact of e-waste leachate on the micronucleus (MN) of Tilapia guineensis and the levels of heavy metals ( $\mathrm{Pb}, \mathrm{Cd}, \mathrm{Cr}, \mathrm{As}, \mathrm{Hg}, \mathrm{Al}$ and $\mathrm{Ba}$ in the sediments, water, leachate and aquatic fauna (Tilapia guineensis, Callinectes amnicola and Cardiosoma armatum) found in and around e-waste dumpsites in Lagos and Osun States was studied. The levels of heavy metals were determined using PyeUnicam model 969 Atomic Absorption Spectrophotometry and Inductive Coupling Plasma Atomic Absorption Spectrophotometry (ICP-AAS). The heavy metal concentrations decreased in the order: $\mathrm{Pb}>\mathrm{Cd}>$ $\mathrm{Cr}>\mathrm{Hg}>\mathrm{Al}>\mathrm{Ba}>\mathrm{As}$ in the samples. The level of $\mathrm{Cd}$ in fish muscle from Lagos $(1.4 \mathrm{mg} / \mathrm{kg}$ ) exceeded the Environment Canada threshold effect level (EC TEL, 2006) recommended for sea food $(1.0 \mathrm{mg} / \mathrm{kg})$. The calculated bioconcentration factor (BCF) for fish gills (1.4 and1.0) and fish muscles. (3.6 and 1.2) from Lagos and Osun States respectively as well as the bioaccumulation factor (BAF) for crabs (1.78 and 1.36) are strong indications of the ability of the organisms to bioaccumulate the heavy metals. The MN assay showed an initial increase in the frequency of mionccronuclei on the $7^{\text {th }}$ day which gradually decreased on the $14^{\text {th }}$ and $21^{\text {st }}$ day. The result of this study reveals the toxic impacts of e-waste contamination on ecological and human health in a developing economy.
\end{abstract}

DOI: https://dx.doi.org/10.4314/jasem.v22i3.7

Copyright: Copyright (9) 2018 Igbo et al. This is an open access article distributed under the Creative Commons Attribution License (CCL), which permits unrestricted use, distribution, and reproduction in any medium, provided the original work is properly cited

Dates: Received: 06 February 2018; Revised: 27 February: 2018; Accepted: 28 March 2018

Keywords: E-waste, Micronucleus, Heavy Metals, Aquatic Ecosystem, Contamination

Waste electrical and electronic equipment (WEEE) is composed of approximately $60 \%$ metals, $20 \%$ organic compounds, and $20 \%$ residual materials such as wood or glass (Stankovic et al. 2012). The environmental costs of electronics production and consumption are increasingly affecting peripheral ecosystems and could become important drivers of environmental deterioration and biodiversity loss Jang et al., (2011).This is due to the complex mix of environmental pollutants released during recycling and disposal of e-waste which may irreversibly hamper the ecosystems of many developing Countries like Nigeria. Toxic heavy metals such as lead $(\mathrm{Pb})$, mercury $(\mathrm{Hg})$, arsenic $(\mathrm{As})$, cadmium $(\mathrm{Cd})$ from e-waste are known carcinogens and when dispersed into the environment contaminate the air, surface and groundwater, sediment, biota and soil. In the aquatic ecosystem they readily bioaccumulate in the tissues of the organisms via their diet and become concentrated at levels that are much higher than in the water itself (Chukwu, 2010). The presence of these pollutants in any compartment of the marine environment is of great concern to human societies and this has therefore led to the formulation of several regulatory laws as regards restrictions on using the marine environment as dumping sites and making it compulsory for samples of sea foods to be analyzed for these pollutants before marketing and consumption (Osibanjo et al., 2012). Mercury is one of the most toxic heavy metals contained in the e-waste. It is toxic in very low doses while $\mathrm{Pb}$ is one of the most abundant toxic byproducts of e-waste that is detrimental to human health. Copper $(\mathrm{Cu})$ is found in printed circuit boards and cable use as a catalyst for dioxin and furan formation when flame retardants are burned.

Physical and chemical changes brought about by contamination from these toxicants in the environment are rapidly reflected as measurable physiological changes in fish (Okunola et al., 2011). Several techniques like genotoxicity assays used to detect compounds that induce genetic damage have been employed in the clinical diagnosis of diseases. Genetic assays like the micronucleus (MN) have gained widespread acceptance as indicators of DNA damage and carcinogenicity (Okunola and Bakare, 2011). The increased interest in environmental 
genotoxicity studies is aimed at evaluating genotoxic effects in the aquatic environment. Micronucleus assay (MN) is therefore one of the most popular indicators of DNA damage for over 30 years (Okunola et al., 2012). ). It is sensitive, rapid, and extensively used as a tool for the detection of mutagenic and genotoxic effects of chemicals in the environment. Fishes are used as sentinel organisms that indicate the risk of human exposure through the aquatic food chain. They are therefore important vectors of human contamination. Several measurements of increasing levels of heavy metals in soil, air and water due to anthropogenic activities have been made by earlier workers ( $\mathrm{Hu}, 2000)$ (Chukwu, 2006). Consequently therefore, this present study assesses the levels of some heavy metals of interest in e-waste $(\mathrm{Hg}, \mathrm{As}, \mathrm{Pb}, \mathrm{Ba}, \mathrm{Cd}, \mathrm{Cr}$ and $\mathrm{Al})$ in water, sediment, biota and leachate from e-wastes dumpsites in Lagos and Osun States Southwest, Nigeria, determines the genotoxic effect of e-waste on Tilapia guineensis and calculates the bioaccumulation levels of the organisms to sedimentary particles as well as the toxicity posed to the benthic community by these pollutants.

\section{MATERIALS AND METHODS}

Collection and Analysis of Surface Water, Leachate and Sediment: Surface water samples were collected from the study areas (Figures 1and 2) by dipping water sampler 6-7 $\mathrm{cm}$ below the surface film.

Leachates samples were also collected from 10 different points around the dumpsites with a $1 \mathrm{dm} 3$ water sampler and filtered using $15 \mathrm{~cm}$ whatman filter paper (Okunola et al., 2012). Both samples were stored in 1litre water bottle each with a screw cap, transported to the laboratory for further analysis. Temperature and $\mathrm{pH}$ were measured in situ.

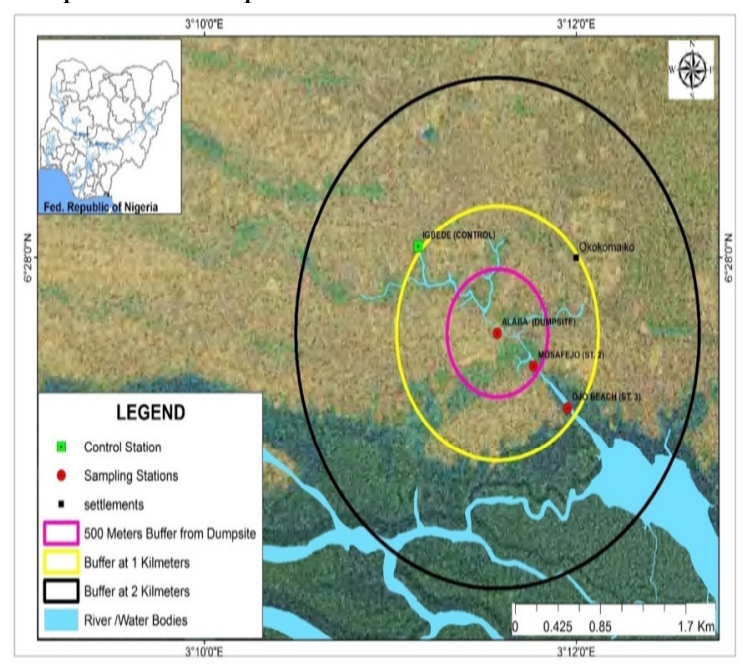

Fig 1: Map of Lagos State Showing Study Stations
Leachate samples were analyzed for a number of standard physico-chemical properties, including $(\mathrm{pH}$, conductivity, salinity, alkalinity and biological oxygen demand (BOD) according to American Public Health Association (APHA, 1998). This was done with a Horiba-U-10 multi meter water checker. Other parameters such as nitrate, phosphate, and sulphate were analyzed using LaMotte spectrophotometer RMN26624 according to United States Environmental Protection Agency (USEPA, 2006). Sediments samples $(0-10 \mathrm{~cm})$ depth $10 \mathrm{~m}$ apart around the e-waste dumpsites were collected with the aid of a stainless grab of the Van-Veen type (Okunola et al., 2012). The sediment samples (100g$200 \mathrm{~g}$ ) were packed with aluminium foil into cleaned polythene bags (Ziploc) and transported to the laboratory where they were pooled to form a composite sample for each study site. Sediments were air dried for one month and ground to powder using a laboratory mortar and pestle, passed through a $2 \mathrm{~mm}$ sieve and stored at $-2^{\circ} \mathrm{C}$ until analysed (Okunola et al., 2012). Services of professional fishermen were employed in fishing using gill nets of $1-3 \mathrm{~cm}$ diameter and cylindrical crab traps (Ayoola and Kuton, 2009). The biological samples used for the test were Tilapia guineensis, Cardiosoma armatum (from Osun State) and Callinectes amnicola (Lagos State).

Heavy Metals Analysis in Water, Leachate, Sediment and Biota: Heavy metals were analyzed in the samples according to the United States Environmental Protection Agency (USEPA 1998) and APHA (1998). Five grams each of sediment and biota and $100 \mathrm{ml}$ of each leachate and water samples were digested by heating with concentrated $\mathrm{HNO}_{3}$ $/ \mathrm{H}_{2} \mathrm{O}_{2}(1: 1, \mathrm{v} / \mathrm{v})$, until the volume was reduced to $3-5$ $\mathrm{ml}$. It was made up to $25 \mathrm{ml}$ with distilled water (FAO/SIDA, 2003).

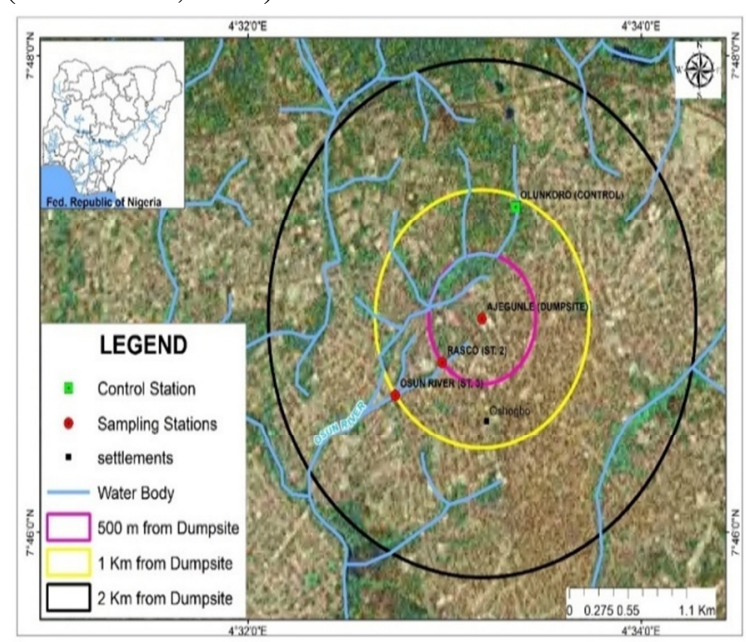

Fig 2: Map of Osun State Showing Study Stations

Igbo, JK; Chukwu, LO; Oyewo, EO; Zelikoff, JT; Jason, BL 
Concentrations of the metals ( $\mathrm{Pb}, \mathrm{Ba}, \mathrm{Cd}, \mathrm{Cr}$ and $\mathrm{Al})$ were estimated by using Pye Unicam model 969 Atomic Absorption Spectrophotometer. Analysis of Mercury and Arsenic using vapour method and Inductively Coupled Plasma (ICP) -Atomic Absorption spectrophotometer: Sample extraction was done by weighing $0.5 \mathrm{~g}$ of sample (sediment and biota) and $100 \mathrm{ml}$ leachate and water in a set of digestion tube and dispensed with perchloric $\left(\mathrm{HC1}_{04}\right)$ acid : nitric acid $\left(\mathrm{HNO}_{3}\right)$ : hydrochloric acid $(\mathrm{HCl})$ $(1: 2: 2)$. The samples were digested at $250^{\circ} \mathrm{C}$ for $1 \frac{1 / 2}{2}$ hours allowed to cool to room temperature. Made up to $50 \mathrm{ml}$ volume, using ultra-pure water and covered with a paraffin paper and swirled. The set of samples were transferred to a set of centrifuge tubes, shacked for 20 minutes, centrifuged for 10 minutes at $5000 \mathrm{r}$ $\mathrm{pm}$ and then transferred to a set of cold vapor vials or tubes ready for analysis using cold vapor-Atomic Absorption spectrophotometer interphase with a computer system.

Test Animal: The test animal used for the MN study were juveniles of Tilapia guineensis obtained from the Nigerian Institute for Oceanography and Marine Research. They were acclimatized for 2 weeks in plastic tank (40L capacity) at $26 \pm 2{ }^{\circ} \mathrm{C}$, during which they were fed with commercial fish pellet. The natural photoperiod was maintained during the acclimatization and experimental periods and test solution was kept oxygenated with an aerator. Test solution was changed every other day.

Micronucleus Study: Three different concentrations (20\%, 40\%, and 60\%) were prepared and 10 fishes each with a control group in replicates were exposed to sub lethal concentration of the test leachate for 21 days and the animals from each of the concentrations were used to assess micronuclei. Test solution was changed every other day. Blood of 3 fishes from each of the different concentrations was drawn with minimum stasis from the fin on the $7^{\text {th }}, 14^{\text {th }}$ and $21^{\text {st }}$ day and used for the analysis. A smear was prepared on glass slide and fixed with methanol for $5 \mathrm{~min}$, air dried and stained with $2 \%$ Giemsa. The slides were scanned and analysed for 1000 cells/individuals with micronuclei.

Ecological Risk Assessment (ERA): For ERA, three different categories of consensus based sediment quality guidelines (SQG) namely threshold effect concentration (TEC), probable effect concentration (PEC) and extreme effect concentration (EEC) according to Long et al., (1995) were used.
Bioaccumulation/ Bioconcentration Factor $(B A F / B C F)$ in Sediment and Biota: This was calculated according to Barmaurd et al., (1998)

Statistics: Descriptive statistics (mean values) were used for the heavy metals. Analysis of variance was performed on all experimental data and means were compared using SPSS version 20.0 software. Results of micronucleus assay were expressed as mean \pm S.E of the triplicates for each leachate sample. The mean values of each leachate sample were compared with the negative control using one-way ANOVA.

\section{RESULTS AND DISCUSSION}

Composition of E-waste Streams from the two Dumpsites: Figure 3 are the most common items recorded at the dumpsites. Larger volumes of waste were recorded in Lagos than in Osun and this was attributed to a higher density market in Lagos. Both dumpsites are situated in market places that serve also as residential areas and it was observed that the waste are constantly burnt in order to reduce the volume. It was observed that items with shorter lifespans (3-5 years) like television, mobile phones, laptops and computers were more abundant at the dumpsites than items like refrigerators and microwaves with longer lifespan $(10-12$ years $)$. This was attributed to their life spans which is in agreement with Robinson (2009) who reported that the contribution of an item to the annual e-waste production (kg/year) depends on the mass of the item, the number of the units in service and its average lifespan. Thus according to him, items like computers which have an average lifespan of three years (Betts, 2008) comprise a greater proportion of WEEE than refrigerators and ovens which have lifespans of 10-12 years.

Physicochemical Properties of Surface Water from the two Dumpsites: The physicochemical parameters of water from e-wastes dumpsites in Lagos and Osun are presented in Table 1. In Lagos, turbidity, alkalinity, dissolved oxygen levels of water were significantly different $(p<0.05)$ from the control while in Osun conductivity, turbidity, and dissolved oxygen levels of water were also significantly different from the control. The temperature range of water from the two dumpsites during the period of study showed that the two environments are typical tropical aquatic ecosystems (temperature range $25.69^{\circ} \mathrm{C}-28.02^{\circ} \mathrm{C}$ ) in agreement with earlier studies (Edokpayi and Nkwoji, 2007). The dissolved oxygen (DO) levels (3.47-3.57 mg/L) in water from Lagos and Osun respectively suggested a non-stressed 
environment for aquatic organisms living in the water bodies.

The low levels of biological oxygen demand (BOD) (0.9 -2.04 mg/L) and nutrients (sulphate (17-38.13 $\mathrm{mg} / \mathrm{L})$ nitrate $(0.11-2.26 \mathrm{mg} / \mathrm{L})$ and phosphate $(20.11$ - $21.04 \mathrm{mg} / \mathrm{L})$ ) indicated an environment that is not organically polluted (Nwankwo, 2004). A high level of BOD and low level of DO usually depict an organically polluted environment (Chukwu, 2006).

Physicochemical Properties of leachate from the two Dumpsites. In leachates from both States turbidity, DO, silicate and sulphate were also statistically different $(\mathrm{p}<0.05)$ from the control (Table 1$)$.
Turbidity was particularly high in the leachate from both States which was attributed to high particulate matters from the e- waste in the dumpsites. High turbidity makes pollutants bioaccessible to organisms, thus organisms living in areas with high turbidity will have higher concentrations of pollutants (Baumard et al (1998). DO levels (1.96 - $2.82 \mathrm{mg} / \mathrm{L})$ depict a hypoxic environment (Edpkpayi and Nkwoji, 2007). Dissolved oxygen level of less than $3 \mathrm{mg} / \mathrm{L}$ is stressful to most aquatic organisms as most fishes die at 1-2 mg/L (Chukwu, 2006).

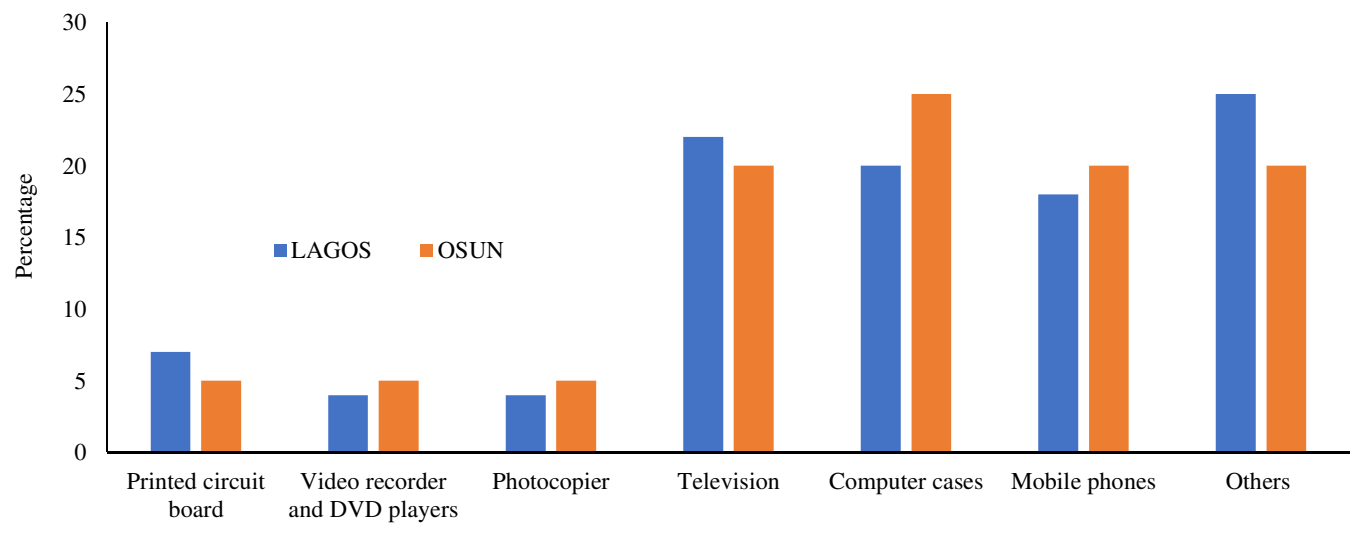

Fig 3: Composition of the wastes stream found at Lagos and Osun e-waste dumpsites

Table 1: Physicochemical Parameters of the Water and Leachates (mg/L) in Lagos and Osun States

\begin{tabular}{|c|c|c|c|c|c|c|c|c|c|c|}
\hline & \multirow[b]{2}{*}{ Water } & \multirow{2}{*}{ Leachate } & \multirow[t]{2}{*}{ Lagos } & \multirow[b]{2}{*}{ ontrol } & \multicolumn{2}{|c|}{ Osun } & & \multirow[b]{2}{*}{ Control } & \multirow{2}{*}{$\begin{array}{l}\text { US EPA } \\
(2009)\end{array}$} & \multirow{2}{*}{$\begin{array}{l}\text { NESREA } \\
(\mathbf{2 0 0 9 )}\end{array}$} \\
\hline & & & & & Water & Leachat & & & & \\
\hline Parameters & $\begin{array}{l}\text { Mean } \\
\pm \text { SE }\end{array}$ & $\begin{array}{l}\text { Mean } \\
\pm \text { SE }\end{array}$ & $\begin{array}{l}\text { t-stat. } \\
\text { (p-value) }\end{array}$ & $\begin{array}{l}\text { Mean } \\
\pm S E\end{array}$ & $\begin{array}{l}\text { Mean } \\
\pm S E\end{array}$ & $\begin{array}{l}\text { Mean } \\
\pm S E\end{array}$ & $\begin{array}{l}\text { t-stat. } \\
\text { (p-value) }\end{array}$ & Mean \pm SE & & \\
\hline Air Temp. & $26.98 \pm 0.51$ & $27.25 \pm 0.56$ & $0.286(0.776)$ & $26.38 \pm 1.46$ & $26.50 \pm 0.47$ & $26.06 \pm 0.40$ & $0.542(0.592)$ & $27.59 \pm 0.41$ & $n a$ & $n x$ \\
\hline Water Temp. & $28.02 \pm 0.46$ & $28.69 \pm 0.62$ & $0.754(0.457)$ & $27.44 \pm 1.56$ & $26.65 \pm 0.99$ & $25.69 \pm 2.00$ & $0.579(0.567)$ & $27.76 \pm 0.54$ & 2.3 & $n .2$ \\
\hline Salinity & $0.54 \pm 0.10$ & $0.52 \pm 0.20$ & $0.414(0.682)$ & $0.42 \pm 0.20$ & $0.10 \pm 0.04$ & $0.09 \pm 0.04$ & $0.135(0.894)$ & $0.12 \pm 0.05$ & 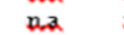 & \\
\hline $\mathrm{pH}$ & $7.52 \pm 0.07$ & $7.85 \pm 0.20$ & $1.971(0.058)$ & $7.54 \pm 0.15$ & $7.98 \pm 0.10$ & $8.05 \pm 0.22$ & $488(0.629)$ & $7.73 \pm 0.08$ & $6.5-8$ & $6-9$ \\
\hline Conductivity & $2.74 \pm 0.45$ & $2.35 \pm 0.10$ & $0.494(0.625)$ & $3.21 \pm 1.31$ & $0.68 \pm 0.15$ & $1.21 \pm 0.22$ & $2.434^{*}(0.021$ & $1.19 \pm 0.15$ & n.2. & n.2. \\
\hline Turbidity & $30.42 \pm 26.53$ & $68.00 \pm 22.21$ & $3.60 *(0.001)$ & $10.50 \pm 1.77$ & $32.94 \pm 7.17$ & $65.17 \pm 13.5$ & $2.956^{*}(0.006$ & $30.50 \pm 8.12$ & a.2. & n. \\
\hline Alkalinity & $43.00 \pm 5.51$ & $92.13 \pm 10.95$ & $4.304^{*}(0.000$ & $10.56 \pm 0.72$ & $35.01 \pm 5.94$ & $92.00 \pm 20.2$ & $3.908 *(0.000$ & $22.13 \pm 5.91$ & 20 & 15 \\
\hline DO & $3.47 \pm 2.25$ & $1.96 \pm 1.37$ & $1.78^{*}(0.085)$ & $6.78 \pm 1.35$ & $3.52 \pm 1.58$ & $2.82 \pm 1.80$ & $1.269 *(0.214$ & $4.75 \pm 0.94$ & na & 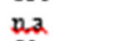 \\
\hline BOD & $0.90 \pm 0.28$ & $1.85 \pm 0.55$ & $1.65(0.110)$ & $0.55 \pm 0.14$ & $2.04 \pm 0.33$ & $1.45 \pm 0.32$ & $1.175(0.249)$ & $0.21 \pm 0.17$ & 250 & \\
\hline Silicate & $29.75 \pm 2.49$ & $59.000 \pm 5.19$ & $5.58(0.00)$ & $0.51 \pm 0.23$ & $16.06 \pm 1.50$ & $23.67 \pm 2.69$ & $2.514 *(0.018$ & $11.76 \pm 3.42$ & Da. & $n a$ \\
\hline Nitrate & $0.66 \pm 0.21$ & $1.84 \pm 0.65$ & $2.26(0.031)$ & $0.11 \pm 0.05$ & $0.26 \pm 0.05$ & $0.64 \pm 0.36$ & $1.759(0.089)$ & $0.47 \pm 0.14$ & 10 & \\
\hline & $21.04 \pm 4.86$ & $20.11=4.24$ & $0.461(0.648)$ & $0.15 \pm 0.08$ & $19.84 \pm 1.19$ & $20.03 \pm 2.82$ & $0.733(0.469)$ & $5.19 \pm 2.61$ & 5 & 2 \\
\hline Sulphas & $38.17 \pm 5.22$ & $28.13 \pm 10.73$ & $4.11^{*}(0.00)$ & $0.08 \pm 0.02$ & $52.22 \pm 0.94$ & $17.00 \pm 6.00$ & $4.427(0.77)$ & $38.16 \pm 12.12$ & $2 \mathrm{nz}$ & D. \\
\hline
\end{tabular}

* Significant level at $p<0.05 .$. n.a: data not available. Units are in $\mathrm{mg} / \mathrm{L}$ except conductivity $(\mu \mathrm{S} / \mathrm{cm})$, salinity (ppm) Temperature $\left(O^{c}\right)$ and pH which has no unit. BOD-biological oxygen demand. NESREA- National Environmental Standards Regulation and Enforcement Agency

Table 2: The Pearson Correlation Matrix Index for the Heavy Metals

\begin{tabular}{lllllll}
\hline Metals & $\mathrm{Cr}$ and $\mathrm{Pb}$ & $\mathrm{Cd}$ and $\mathrm{Pb}$ & $\mathrm{Cd}$ and $\mathrm{Cr}$ & $\mathrm{Hg}$ and $\mathrm{Pb}$ & $\mathrm{Hg}$ and $\mathrm{Cd}$ & $\mathrm{As}$ and $\mathrm{Pb}$ \\
$\mathbf{r}^{\mathbf{2}}$ & 0.34 & 0.25 & 0.53 & 0.40 & 0.56 & 0.12 \\
\hline
\end{tabular}

Table 3: The calculated BCF and BAF of Tilapia guineensis (gills, muscles) from Lagos and Osun States.

\begin{tabular}{llcll}
\hline & \multicolumn{2}{c}{ BAF } & \multicolumn{2}{c}{ BCF } \\
LAGOS & Calinectes amnicola & Cardiosoma armatum & Fish Muscles & Fish Gills \\
OSUN & 1.78 & - & 3.6 & 1.4 \\
\hline
\end{tabular}

Igbo, JK; Chukwu, LO; Oyewo, EO; Zelikoff, JT; Jason, BL 
Distribution Pattern of Heavy Metal Burdens in the Studied Samples from the two Dumpsites: The following heavy metals ( lead $(\mathrm{Pb})$, cadmium $(\mathrm{Cd})$, chromium (Cr), mecury ( $\mathrm{Hg})$, asernic (As), aluminum(Al) and baruim (Ba)) were measured in water, leachate, sediment, Tilapia guinensis (muscles and gills), and crabs (Callinectes amnicola and Cardiosoma armatum) from Lagos and Osun States . The result reveald relatively higher heavy metal burdens in Lagos samples than in Osun (Figure 4) which was attributed to the density, age and composition of the wastes stream in the two electronic markets. Lagos has a higher density market than Osun. The mean heavy metal burden occurred in the following decreasing order in the studied samples: Lagos leachate $(125.3 \mathrm{mg} / \mathrm{L})>$ Callinectes spp $(114.5 \mathrm{mg} / \mathrm{kg})>$ Osun leachate $(102.0 \mathrm{mg} / \mathrm{L})>$ Lagos fish muscles $(94.85 \mathrm{mg} / \mathrm{kg})>$ Cardiosoma $\mathrm{spp}$ $(74.5 \mathrm{mg} / \mathrm{kg})>$ Lagos sediment $(64.26 \mathrm{mg} / \mathrm{kg})>$ Osun sediments $(54.76 \mathrm{mg} / \mathrm{kg})>$ Lagos fish gill $(38.53 \mathrm{mg} / \mathrm{kg})>$ Osun fish muscles $(3121 \mathrm{mg} / \mathrm{kg})>$ Lagos water $(26.16 \mathrm{mg} / \mathrm{L})>$ Osun water $(23.85$ $\mathrm{mg} / \mathrm{L})$. There was observed elevated leve; of $\mathrm{Pb}$ and $\mathrm{Cd}$ in some of the samples studied which was attributed to their bioavailability in the studied environments (Baumard et al., 1998). There was no signficant difference between the metal concentrations in the wet and the dry season.

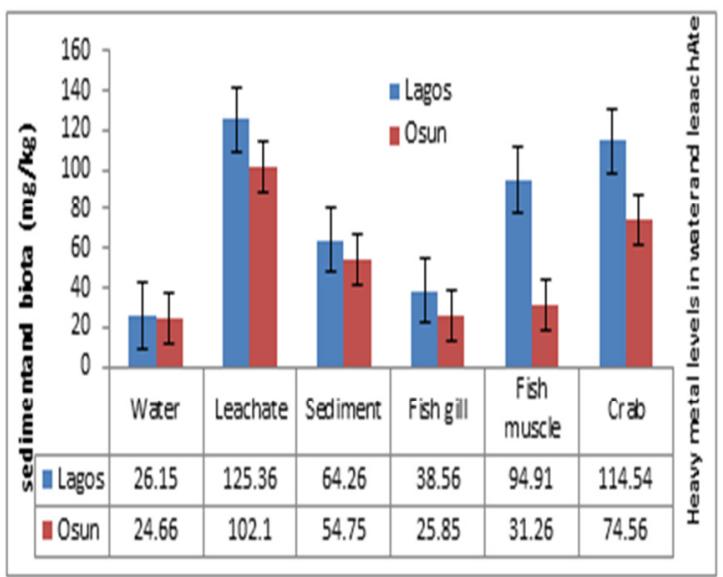

Fig 4: Heavy metal burdens in the samples from Lagos and Osun States e-waste dumpsites. $(\mathrm{n}=8)$

Evaluation of Heavy Metals in Water from the two Dumpsites: In Figure 5 below, the levels of $\mathrm{Pb}, \mathrm{Cd}$ and $\mathrm{Cr}$ exceeded the USEPA (2003) and NESREA (2009) maximum permissible limit standards in water. The metal mecury $(\mathrm{Hg})$ exceeded the USEPA (2009) limit standard in water from Lagos state. Pb in the water is from printed circuit board and computer board, $\mathrm{Hg}$ is from relays and switches and printed circuit board while $\mathrm{Cr}$ is from galvanized steels. This non- essential metals are toxic at very low levels and constitute significant potential threats to both occupational and environmental health $(\mathrm{Hu}$, 2000).

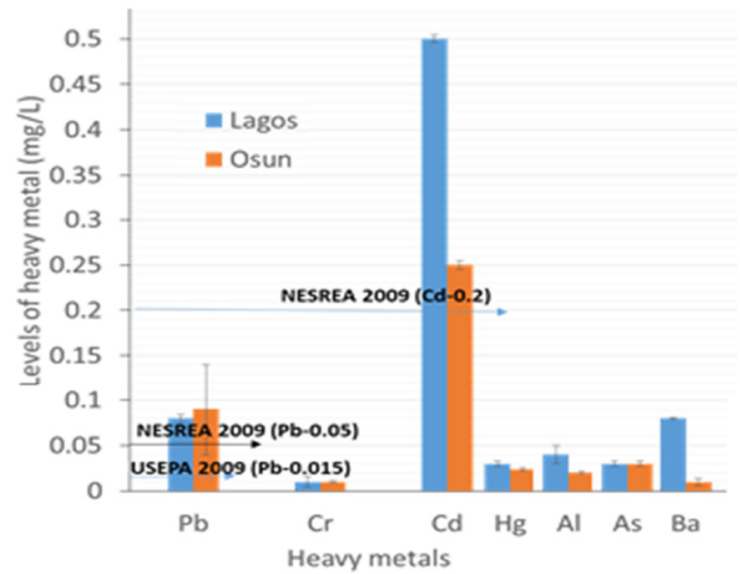

Fig 5 Mean Levels of heavy metals in water samples from Lagos and Osun States e-waste dumpsites. $(\mathrm{n}=8)$

Evaluation of Heavy Metals in Leachate from the two Dumpsites: The metal $\mathrm{Cd}$ exceeded the USEPA (2003) limit standard $(0.01 \mathrm{mg} / \mathrm{L})$ for treated waste water in leachate.from Lagos state (Figure 6) and this was attributed to the high numbers of computers and other items recorded at the dumpsites. The high level of this metal is an implication of the toxic nature of the leachate. The source of $\mathrm{Cd}$ is from chip resistors (Tsydenova and Bengtsson 2009). Cd, $\mathrm{Hg}$ together with $\mathrm{Pb}$ and $\mathrm{As}$ are the four most toxic non essential metals and therefore exert toxicity effects at any level of exposure (Jang, 2011).

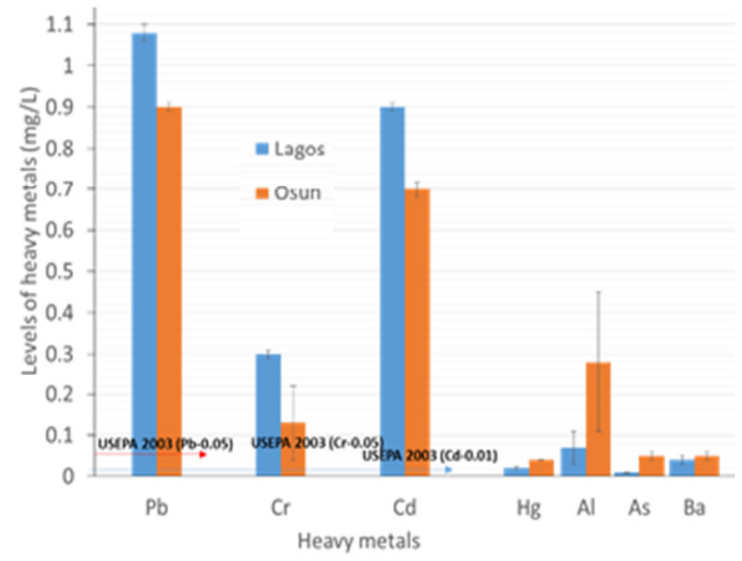

Fig 6: Mean levels of heavy metals in leachate from Lagos and Osun States. $(n=8)$

Evaluation of Heavy Metals in Sediment from the two Dumpsites: Figure 7 shows that the metal levels ranged from $(57.15-0.3 \mathrm{mg} / \mathrm{kg})$ to $(48.02-0.02$ $\mathrm{mg} / \mathrm{kg}$ ) in sediment from Lagos and Osun State

Igbo, JK; Chukwu, LO; Oyewo, EO; Zelikoff, JT; Jason, BL 
respectively occurring in the following decreasing order: $\mathrm{Fe}>\mathrm{Cu}>\mathrm{Pb}>\mathrm{Cr}>\mathrm{Cd}>\mathrm{Hg}>\mathrm{Al}>$ As. Ba. The high metal levels recorded in the sediment samples confirmed that it is a major repository of heavy metals in the aquatic ecosystem (Olowu et al., 2010).

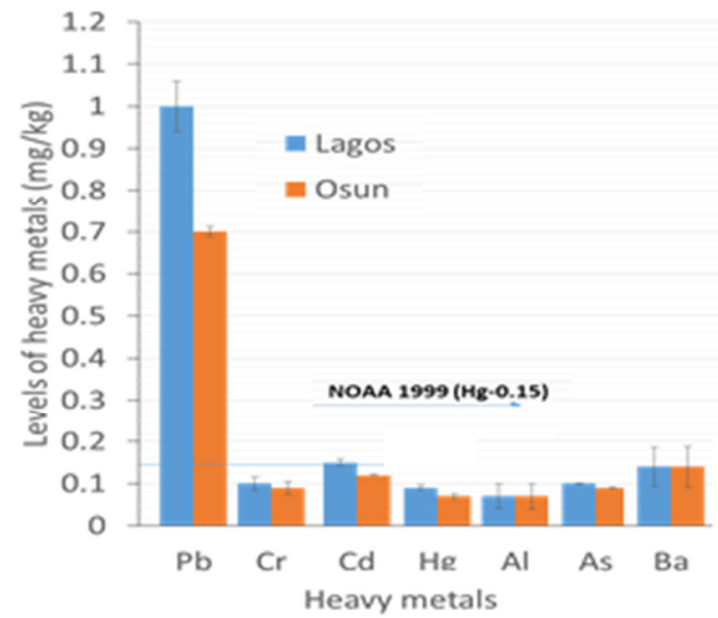

Fig 7 Mean levels of heavy metals in sediments from Lagos and Osun States Mean $(\mathrm{n}=8)$

Evauation of Heavy Metals in Biota from the two Dumpsites: Heavy metal burdens occurred in the following decreasing order in the samples: Callinectes spp $(114.54 \mathrm{mg} / \mathrm{kg})>$ fish muscles from Lagos $\quad(94.91 \mathrm{mg} / \mathrm{kg})>$ Cardiosoma spp $\quad(74.56$ $\mathrm{mg} / \mathrm{kg})>$ fish gills from Lagos $(38.56 \mathrm{mg} / \mathrm{kg})>$ fish muscles from Osun $(31.26 \mathrm{mg} / \mathrm{kg})>$ Fish gills from Osun $(2585 \mathrm{mg} / \mathrm{kg}$ ) (Figure 8).

Cd levels exceeded the EC TEL 2006 permissible limit for seafood. This observation could be due to major functional differences in the body of the organisms. Similar comparison on heavy metal accumulation between crabs and fishes have been reported by Olowo et al., (2010). This variation could also be due to the degree to which the different organisms pick their matter from surrounding water and in particular the sediment while feeding.

Crabs are bottom feeders and therefore generally expected to concentrate more heavy metals than pelagic fishes like Tilapia spp. The high heavy metal levels recorded in the muscles of $T$. guinensis confirmed that these pollutants are lipophilic (Oyewo, 1998). Contamination of the gills was attributed to the pollution of the water colunm by the heavy metals because of the frequent contact between the gills and water. There was no significant difference $(p<0.05)$ in the concentration of heavy metals recorded in the wet and the dry season (Figure 9)

Igbo, JK; Chukwu, LO; Oyewo, EO; Zelikoff, JT; Jason, BL

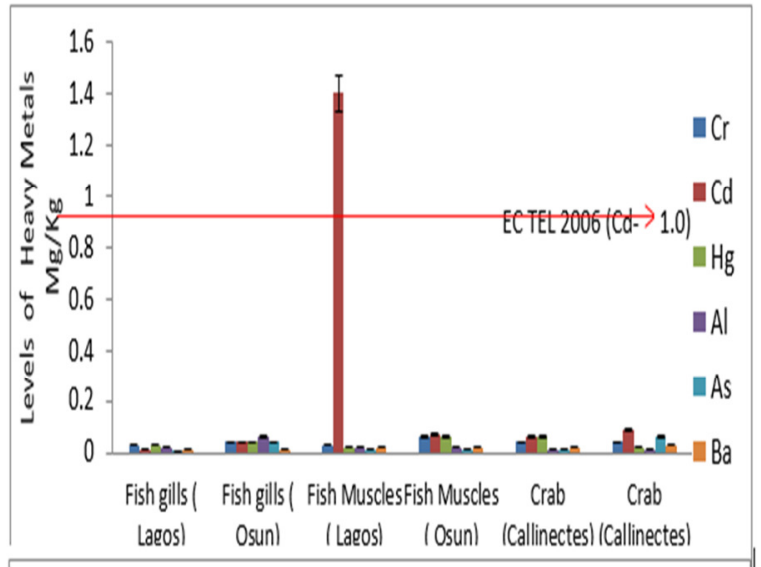

Fig 8: Mean levels of heavy metals in Tilapia guineensis (gills, muscles) and crabs (Callinectes amnicola and Cardiosoma armatum) from Lagos and Osun States $(\mathrm{n}=8)$

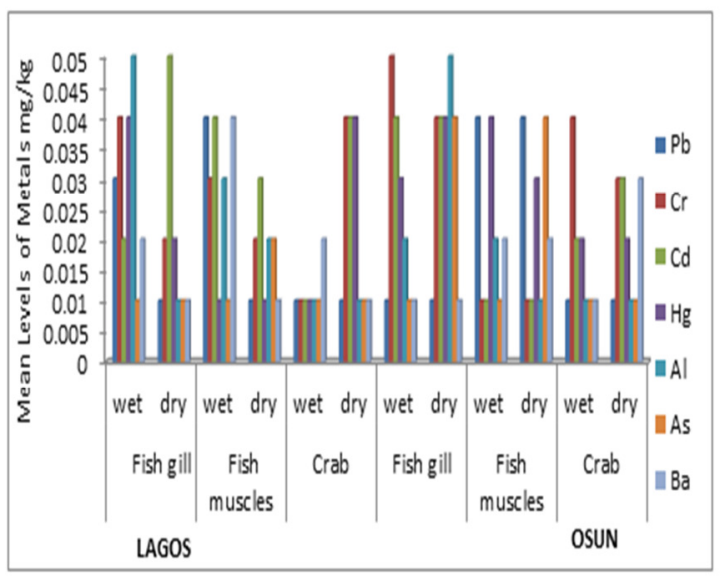

Fig 9: Seasonal Variation in Heavy Metal Levels metals in Tilapia guineensis (gills, muscles) and crabs (Callinectes amnicola and Cardiosoma armatum $)(\mathrm{mg} / \mathrm{kg}$ wet weight) from Lagos and Osun States. $(\mathrm{n}=8)$

The BCF/BAF: The weak Pearson correlation matrix index (Table 2) are strong indications that heavy metals contamination of e-waste leachate are from different types of electronic equipment. The calculated BCF for fish gill and fish muscles from Lagos and Osun States respectively as well as the BAF for crabs (Table 3) from the two States indicate that the organisms have the ability to bioaccumulate the pollutants. However, fish muscle from Lagos has a higher tendency to bioaccumulate the heavy metals (about three times) more than the other organs due to its lipophicity (Oyewo, 1998). Heavy metals are fat loving (lipophilic) and therefore are bioaccumulative. High lipophilicity results in the substance bioconcentrating from the surrounding medium into the organism. 
Table 4: Physico-chemical parameters and heavy metals (mg/L) levels of the leachate used for the MN assay

\begin{tabular}{|l|l|l|l|}
\hline Parameters & $\begin{array}{l}\text { Mean } \\
\pm \text { SE }\end{array}$ & $\begin{array}{l}\text { USEPA } \\
(2009)\end{array}$ & $\begin{array}{l}\text { NESREA } \\
(2009)\end{array}$ \\
\hline DO & $2.82 \pm 1.80$ & - & - \\
\hline BOD & $1.45 \pm 0.32$ & -250 & -50 \\
\hline salinity & $0.09 \pm 0.04$ & $6.5-8.5$ & $6-9$ \\
\hline alkalinity & $92.00 \pm 20.25$ & 20 & 150 \\
\hline Conductivity & $1.21 \pm 0.22$ & - & - \\
\hline pH & $8.05 \pm 0.22$ & - & - \\
\hline Nitrate & $0.64 \pm 0.36$ & 10 & 10 \\
\hline Phosphate & $20.03 \pm 2.82$ & 5 & 2 \\
\hline Sulphate & $17.00 \pm 6.00$ & - & - \\
\hline Lead & 0.2 & - & - \\
\hline Cadmium & 0.7 & 0.05 & 0.005 \\
\hline Chromium & 0.4 & 0.1 & 0.05 \\
\hline Mercury & 0.02 & - & - \\
\hline Arsenic & 0.01 & - & - \\
\hline
\end{tabular}

Units are in $\mathrm{mg} / \mathrm{L}$ except conductivity $(\mu \mathrm{S} / \mathrm{cm})$, salinity $(\mathrm{ppm})$ Temperature $\left(0^{\mathrm{c}}\right)$ and $\mathrm{pH}$ which has no unit. NESREA- National Environmental Standards Regulation and Enforcement Agency. USEPA:

Combined with environmental persistence and a resistance to biological degradation, lipophilicity also results in biomagnification through the food chain which in turn leads to much greater exposures in organisms at the top of the food chain. In the aquatic environment, they are absorbed by fish and other aquatic organisms into the organs that are rich in lipids, those that are not rapidly metabolized are retained in the fat. This results in accumulation of the pollutants in smaller organisms which are then eaten by the bigger ones and this continues all the way up the food chain to the organisms in the higher trophic levels and eventually gets to humans.

Micronucleus Study of Tilapia guineensis: The micronucleus assay (Table 5) carried out with peripheral blood erythrocytes of $T$. guineensis exposed to electronic wastes leachate induced increased concentration dependent micronuclei (MN) frequencies on the $7^{\text {th }}$ and $14^{\text {th }}$ day which gradually decreased as the exposure progressed to the $21^{\text {st }}$ day compared to the control with lower frequencies of micronuclei. This is in agreement with Campana et al., (1995) who worked on micronucleus frequencies in peripheral erythrocytes of Cheirodon interruptus treated with lambda-cyhalothrin and cyclophosphamide. The authors observed initial dose dependent increase in the number of micronuclei frequencies which gradually decreased over 14 and 21 days showing that erythrocytes were good bioindicators to demonstrate the hazardous effects of the compound in low concentrations (Okunola and Bakare, 2011). Similarly, Torres de Lemos et al.,
(2001) reported that micronuclei induction by chromium in erythrocytes of Pimepheles promelas exhibited a decrease after the 21 day exposure period. This findings confirmed that erythrocytes are weak biomarkers of genotoxicity for 21 days of the exposure period (Tolga et al., 2005). The formation of micronuclei was attributed to an increase in clastogenic or aneugenic accidents in response to the toxicant. Formation of nuclear abnormalities along with $\mathrm{MN}$ in erythrocytes of fish is considered as possible indicators of genotoxicity when investigating the effects of pollutants in aquatic species (Delemos et al., 2007). A study by Bakare et al., (2007) reported that clastogenic and aneugenic substances from industrial effluents discharged into the sea resulted in the formation of micronucleus in the erythrocyte of grey mullet (Mugil cephalus). According to Okunola and Bakare (2011) induction of $\mathrm{MN}$, might be as a result of the leachates absorption into the cells and change in the $\mathrm{pH}$ within and outside the cells, which might affect the activities of enzymes and change the structure of DNA

Table 5: Effect of sub-lethal exposure of leachate on the micronucleus of Tilapia guineensis (mean $\pm \mathrm{SE}$ ). *significant ( $\mathrm{p} \leq$

\begin{tabular}{|c|c|c|c|c|c|}
\hline \multicolumn{6}{|c|}{7 days exposure } \\
\hline Parameters & Control & $\begin{array}{l}20 \% \\
\text { Conc. }\end{array}$ & $\begin{array}{l}40 \% \\
\text { Conc. }\end{array}$ & $\begin{array}{l}60 \% \\
\text { Conc. }\end{array}$ & $\begin{array}{c}\text { p- } \\
\text { value }\end{array}$ \\
\hline $\begin{array}{l}\text { RBC } \\
\text { Counted }\end{array}$ & $\begin{array}{c}1533 \\
\pm 109.3 \\
\end{array}$ & $\begin{array}{c}1458 \\
\pm 196.3 \\
\end{array}$ & $\begin{array}{r}1450 \\
\pm 57.7 \\
\end{array}$ & $\begin{array}{c}1420 \\
\pm 57.7 \\
\end{array}$ & 0.279 \\
\hline $\begin{array}{l}\text { RBC with } \\
\text { Micronucleus }\end{array}$ & ND & $1 \pm 0.3$ & $3 \pm 0.3$ & $3 \pm 0.0$ & 0.067 \\
\hline $\begin{array}{l}\text { \% RBC with } \\
\text { Micronucleus }\end{array}$ & 1 & $\begin{array}{c}1 \\
(33.3 \%)\end{array}$ & $\begin{array}{c}3 \\
(37.3 \%) \\
\end{array}$ & $\begin{array}{c}3 \\
(37.3 \%) \\
\end{array}$ & \\
\hline & \multicolumn{5}{|c|}{14 days exposure } \\
\hline Parameters & Control & $\begin{array}{l}20 \% \\
\text { Conc. }\end{array}$ & $\begin{array}{l}40 \% \\
\text { Conc. }\end{array}$ & $\begin{array}{l}60 \% \\
\text { Conc. }\end{array}$ & $\begin{array}{c}\text { p- } \\
\text { value }\end{array}$ \\
\hline $\begin{array}{l}\text { RBC } \\
\text { Counted }\end{array}$ & $\begin{array}{r}1433 \\
\pm 44.1\end{array}$ & $\begin{array}{r}1340 \\
\pm 83.3\end{array}$ & $\begin{array}{c}1297 \\
\pm 123.9\end{array}$ & $\begin{array}{r}1217 \\
\pm 83.3\end{array}$ & 0.423 \\
\hline $\begin{array}{l}\text { RBC with } \\
\text { Micronucleus }\end{array}$ & ND & $1 \pm 0.3$ & $2 \pm 0.9$ & $1 \pm 0.7$ & 0.256 \\
\hline $\begin{array}{l}\% \text { RBC with } \\
\text { Micronucleus }\end{array}$ & ND & $\begin{array}{c}1 \\
(25.0 \%)\end{array}$ & $\begin{array}{c}2 \\
(50.0 \%)\end{array}$ & $\begin{array}{c}2 \\
(25.0 \%)\end{array}$ & \\
\hline & \multicolumn{5}{|c|}{21 days exposure } \\
\hline Parameters & Control & $\begin{array}{l}20 \% \\
\text { Conc. }\end{array}$ & $\begin{array}{l}40 \% \\
\text { Conc. }\end{array}$ & $\begin{array}{l}60 \% \\
\text { Conc. }\end{array}$ & $\begin{array}{c}\text { p- } \\
\text { value }\end{array}$ \\
\hline $\begin{array}{l}\text { RBC } \\
\text { Counted }\end{array}$ & $\begin{array}{r}1233 \\
\pm 72.6\end{array}$ & $\begin{array}{l}1207 \\
\pm 148.1\end{array}$ & $\begin{array}{c}1187 \\
\pm 157.3\end{array}$ & $\begin{array}{c}1080 \\
\pm 60.88\end{array}$ & 0.709 \\
\hline $\begin{array}{l}\text { RBC with } \\
\text { Micronucleus }\end{array}$ & $1 \pm 0.3$ & $1 \pm 0.3$ & $1 \pm 1.0$ & $1 \pm 0.9$ & 0.108 \\
\hline $\begin{array}{l}\text { \% RBC with } \\
\text { Micronucleus }\end{array}$ & ND & $\begin{array}{c}1 \\
(32.5 \%)\end{array}$ & $\begin{array}{c}1 \\
(33.5 \%)\end{array}$ & $\begin{array}{c}1 \\
(33.0 \%)\end{array}$ & \\
\hline
\end{tabular}
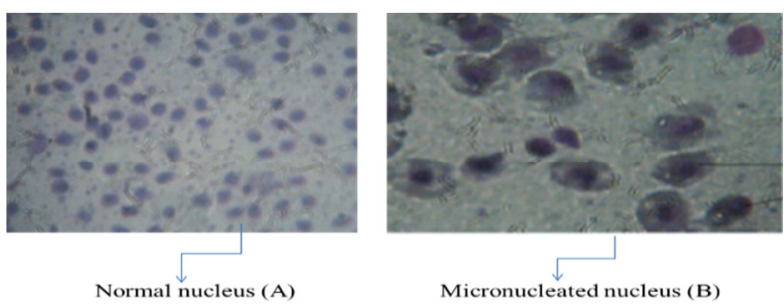

Plate 1A and B: Peripheral blood smear showing normal (A) and micronucleated (B) erythrocyt 
Ecological Risk Assessment (ERA): Comparison of heavy metal values with the EC TEL (2006) and NOAA ERL (1999) guidelines for sediments and seafood revealed that only Cadmium $(\mathrm{Cd})$ level in fish muscle $(1.4 \mathrm{mg} / \mathrm{kg})$ from Lagos was found to be above the EC TEL (1.0mg/kg) (Figure 5).This is suggestive of a highly toxic sample which is likely to cause negative biological effect to humans who consume fish from the e-waste contaminated water in Lagos. Bioaccumulation of $\mathrm{Cd}$ in animals is high compared to most metals because it is assimilated rapidly and excreted slowly $(\mathrm{Hu}, 2000)$. Occupational exposure to $\mathrm{Cd}$ has been linked to pulmonary cancer as well as prostate, renal, liver, hematopoietic system, urinary bladder, pancreatic, and stomach cancers (Suzoko, et al, 2004). However, the potential mechanism(s) of $\mathrm{Cd}$ carcinogenesis is unknown. Although Cd does not form adducts with DNA it can still produce some oxidative stress that could indirectly attack DNA but does not do this by participation in Fenton type chemical reactions (Okunola and Bakare 2011).

Conclusion: In conclusion, the findings in this study confirmed the presence of toxic heavy metals in ewaste leachate from Lagos and Osun States as well as demonstrated that exposure of $T$. guineensis juveniles to varying concentrations of e-waste leachate could be genotoxic to fish. Based on the current findings, it is obvious that there is urgent need for a concerted effort by the authorities to ensure proper disposal, management and enforcement of guidelines, polices and standards in order to address the environmental and health hazards posed by the exposure to e-waste.

\section{REFERENCES}

American Public Health Association (1998). Standard methods for the examination of water and wastewater, (APHA, AWWA, WPCF), 20th Ed., Washington, DC 433pp

Ayoola, SO; Kuton, MP (2009). Seasonal Variation in Fish Abundance and Physicochemical Parameters of Lagos Lagoon, Nigeria, Afri. J. Environ. Sci. and Technol. 3(5):149-156.

Bakare, AA; Pandey, AK; Bajpayee, M; Bhargar, D; Chondhuri, DK; Singh, K P (2007). DNA damage induced on human peripheral blood lymphocyte by industrial solid waste and municipal sludge leachaks. Environ. Mol. Mutagene. 48:30-37.

Baumard, P; Budzinski, H; Michon, Q; Garigues, P; Burgeot; Belloeq, T (1998). Origin and bioavailability of PAHs in the Mediterranean Sea from Mussel and Sediment records. Estuar. Coast. Shelf Sci.47: 77-90.

Betts, K (2008). Producing Usable Materials from ewaste. Environ. Sci. and Technol. 42(18) 67826783.

Campbell, DJV (1993). Environmental Management of Landfill sites. Water Environ. J 7(2) 170-173.

Chukwu, LO (2006). Short-term toxicology and accumulation of heavy metals by African Giant River prawn, Macrobrachium vollenhoevenii (Herklots, 1857) exposed to treated industrial effluents Ecol. Environ. Cons. 12(1): 1-7.

Chukwu, LO; Okafor, AI (2010). Haematological profile of the African lungfish, Protopterus annectens (Owen) of Anambra River, Nigeria. J. Am. Sci. 6 (2): 123-130.

Delemos, CT; Rodel, PM; Ferra, NR; Erdtmann, B (2007). Evaluation Genotoxity of municipal landfill leachate by micronucleaus test using clarias gauidepirous. Res. Environ. life Sci. 4: 116.

Edokpayi, CA and Nkwoji, JA (2007). Annual Changes in the Phyisco-Chemical and Macrobenthic Invertebrate Characteristics of the Lagos Lagoon Sewage Dump Site at Iddo, Southern, Nigeria. Ecol. Environ. Cons. 13(1): 13-18.

Environmental Canada (2006). Supporting working Document for the Environmental screening Assessment of polybrominated Dipheny Ether. Environment Canada, Gatineau. 222p.

$\mathrm{Hu}$, U (2000). Exposures to metals primary concentration: Clinical office 27(200): 983-996.

Jang, YC; Townsend, TG. (2011). Leaching of lead from computer printed wire boards and cathode ray tubes by municipal solid waste landfill leachates. Environ. Sci. Technol 37:4778-84.

Long, ER; MacDonald, DD; Smoth, SL; Calder, FD (1995). Incidence of adverse biological effects within ranges of chemical concentrations in marine and estuarine sediments. Environ. Manage 19 (1):81-97

National Environmental Standards and Regulation Enforcement Agency (NESREA). (Federal Republic of Nigeria Official Gazette), National Environmental (Sanitation and Waste Control). Federal Government of Nigeria, Abuja, Nigeria, 
(2009); FGP112/102009/L000 (OL54).60(96): 1057-1102.

NOAA (National Oceanic and Atmospheric Administration) (1999) Screening quick reference tables (SquiRTs) <http:// response.restoration.noaa.gov/cpr/sediment/squir t/squirt.html. Last viewed 03/07/15

Okunola, AA; Bakare, AA (2011). Genotoity and mutagenicty of electronic waste leachate using animal bioassays. Toxicol. Environ. Chem. 93(5): 1073-1088.

Okunola, AA; Bakare, AA; Xijun, K; Bin, L; Yuling, Z; Xia. H (2012). Comparative evaluation of environmental contamination and DNA damage induced by electronic wastes in Nigeria and China. Sci. Total Environ. 423: 62 - 72.

Olowo, RA; Ayejuyo, oo; Adejoroi, A; Adewuji, GO; Osundiya, MO; Onwordi, CT; Yusuf, KA and Owolabi, MS (2010). Determination of Heavy Metals in Crab and Prawn in Ojo River, Lagos, Nigeria. E-J Chem.7 (2) 526-530

Osibanjo, O; Nnorom, I; Bakare, AO; Okunola, AA (2013) Environmental and public health consequences of adopting crude recovery techniques in e-waste management in developing countries: An emerging global crisis. Nova Science. Ibadan. p.17.

Onwumere, BG; Olademeji, AA (1990). Accumulation of metals and histopathology in Orochromis niloticus exposed to treated NNPC Kaduna (Nigeria) petroleum refinery effluent. Ecotoxicol Environ. Safety, 19: 123-134.

Oyewo, EO. (1998). Industrial sources and distribution of heavy metals in Lagos Lagoon and their biological effects on estuarine animals. Ph.D. Thesis, University of Lagos, Nigeria, p.200.

Robinson, B. H. (2009). E-waste: An assessment of global production and environmental impact. Sci Total Environ. 2:183-191.

Stankovic, S; Jovic, M; Stankovic, A R; Katsikas, L. (2012). Heavy metals in seafood mussel, risk for human health: In Lichtfouse, E.A (ed)
Environmental chemistry for a sustainable world. Nanotechnology Risk 1(10) 978-94.

Suzoko, KT; Katagon, A; Sakuma, Y; Ogra, Y; Ohmichi. M. (2004) Distributions and Chemical forms of Arsenic after intravenous administration of dimethylarsinic and monomethylarsonic acids to rats. Toxicol. Appl. Pharm. 198: 336-44.

Tolga, C; Natashe, NG; Arkhipchuck, V.A (2005) Induction of micronuclei and binuclei in blood, gill and liver cells of fishes subchronically exposed to cadmium chloride and copper sulphate. Food chem. toxicol, 43: 569- 574.

Torres de lemos, C; Rdel, MP; Terra, NR; Erdtmann, MP (2001). Evaluation of basal micronucleus frequency and hexavalent chromium effects in fish erythrocytes. Environ. Toxicol. Chem. 20(6): 1320-1324

Tsydenova, O; Bengtsson, M (2009). Environmental and human health risks associated with the Endof-life treatment of electrical and electronic equipment. Institute for global Environmental Strategies (IGES). Integrated Waste Management and Resource Efficiency Project. Kanagawa p11

US -EPA/NOAA (2006) Predicting toxicity to amphipods from sediment chemistry. Washington DC: National center for Environmental Assessment. Office of research and Development. US Environmental protection Agency.

US-EPA (2003) Guidelines for ecological risk assessment. Washington DC: Us Environmental protection Agency.

Wong, CS; Duzgoren-Aydin, NS; Aydin, A; Wong, MH (2010). Evidence of excessive releases of metals from primitive e-waste processing in Guiyu, China. Environ. Pollut. 148: 62-72.

NOAA (National Oceanic and Atmospheric Administration) (1999) Screening quick reference tables (SquiRTs) http:// response.restoration.noaa.gov/cpr/sediment/squir t/squirt.html. Last viewed 03/07/15 